\title{
The Prevalence of Hepatitis B Virus Infection in a Population on Long-Term Hemodialysis
}

\author{
Gioacchino Li Cavoli Onofrio Schillaci Carmela Zagarrigo Tancredi Vincenzo Li Cavoli \\ Barbara Oliva Angelo Tralongo Franca Servillo Flavia Caputo
}

Nephrology Dialysis with Renal Transplant, Civico and Di Cristina Hospital, Palermo, Italy

Dear Editor,

Although the prevalence and incidence rates among hemodialysis (HD) patients in developed countries have declined over the last 3 decades, Hepatitis B virus (HBV) infection remains a major issue in the HD setting [1]. The isolated finding of $\mathrm{HBcAb}$ in HBsAg-negative subjects is considered an indication of past exposure to HBV and resolved infection, but the use of sensitive techniques to detect HBV-DNA has shown that low levels of viremia are detectable in $\mathrm{HBs}$ Ag-negative/HBcAb-positive subjects. Today, vaccination programs offer the promise of eliminating HBV infection from developed areas, but emigration from countries of the world where $\mathrm{HBV}$ is highly prevalent will result in HBsAg-negative patients with past exposure to $\mathrm{HBV}$, with the likelihood of them developing ESRD and entering the dialysis pool. We investigated the prevalence of $\mathrm{HBV}$ infection in HD patients by analyzing the HBV serological markers of $322 \mathrm{HD}$ patients from January 2016 to June 2017 in Palermo Italy. Among the 322 screened patients, we found 6 were HBsAg-positive (1.8\%); among these patients, 2 had coin- fection with HCV and 1 with HIV; 2 patients were migrant from Africa; all HBsAg-positive patients had history of transfusion but not of illicit drugs abuse. Among the remaining $316 \mathrm{HBsAg-nega-}$ tive patients, we found that 56 were HBcAb-positive (18\%) and 59 were HBsAbpositive (19\%) patients; 32 patients $(10 \%)$ had mixed $\mathrm{HbsAb} / \mathrm{HBcAb}$-positivity; no positive case of IgM-HBcAb-, HBeAg-, or $\mathrm{HBeAb}$-positive was detected; 311 patients were Caucasian; 3 patients had migrated from Africa and 2 patients had migrated from Bangladesh. All serological markers of the HBsAg-negative patients are summarized in Table 1. Despite the decline of $\mathrm{HBV}$ infection worldwide in the general population, the most recent reports show a persistent presence of $\mathrm{HBV}$ in HD setting. Data from Regional Italian Registries on $\mathrm{HBsAg-positivity} \mathrm{in} \mathrm{HD}$ patients range from 0.6 to $2.2 \%$ [2]. In the general population, $\mathrm{HBcAb}$ is a long-life serological marker of previous HBV infection and it is found in persons with chronic infection as well as in those who recover from infection. In Italy, the prevalence of HBsAg-
Table 1. Serological HBV-HCV-HIV markers in 316 Sicilian HBsAg-negative hemodialysis patients

\begin{tabular}{lc}
\hline Markers & $\begin{array}{c}\text { Number of } \\
\text { patients, \% }\end{array}$ \\
\hline HBsAb/HBcAb-negative & $201(63)$ \\
Total HBsAb-positive & $59(19)$ \\
Total HBcAb-positive & $56(18)$ \\
Isolated HBcAb positive & $24(8)$ \\
Mixed HBcAb-positive/ & $32(10)$ \\
$\quad$ HbsAb-positive & $23(7)$ \\
Total HCVAb-positive & \\
Mixed HCVAb-positive/ & $11(3)$ \\
$\quad$ HBcAb-positive & $3(0.9)$ \\
HIVAb-positive &
\end{tabular}

negative/HBcAb-positive subjects among first-time blood donors ranges from 4.85 to $8.3 \%$ [3-4]. In clinical practice, the presence of $\mathrm{HBcAb}$ in HBsAg-negative/ $\mathrm{HBs} A b$-negative subjects is considered an important key for occult $\mathrm{HBV}$ infection
KARGER

(c) 2018 S. Karger AG, Basel

E-Mail karger@karger.com

www.karger.com/bpu
Dr. Gioacchino Li Cavoli

Nephrology Dialysis with Renal Transplant

Francesco Cilea 43

IT-90144 Palermo Sicily (Italy)

E-Mail gioacchinolicavoli@libero.it 
tracking in the general population, in HD patients and in renal transplant recipients [5]. The relevant $\mathrm{HBcAb}$-positivity rate in HD patients highlights the existing prevalence of risk of HBV spread in HD facilities.

\section{References}

1 World Health Organization-WHO: Hepatitis B and Hepatitis C. Updated July 2017. http:// www.who.int/mediacentre/factsheets/en/ (accessed October 21, 2017).

2 www.sin-ridt.org: Regional Registries Reports.

3 Manzini P, Girotto M, Borsotti R, Giachino $\mathrm{O}$, Guaschino R, Lanteri M, et al: Italian blood

\section{Ethics Statement}

The authors state that subjects gave their informed consent and that the study protocol was approved by the institute's committee on human research.

donors with anti-HBc and occult hepatitis B virus infection. Haematologica 2007;92: 1664-1670.

-4 Romanò L, Velati C, Cambiè G, Fomiatti L, Galli C, Zanetti AR; SIMTI study group for HBV infection among first-time blood donors: Hepatitis B virus infection among firsttime blood donors in Italy: prevalence and

\section{Disclosure Statement}

The authors declare that no conflicts of interest exist.

correlates between serological patterns and occult infection. Blood Transfus 2013;11: 281-288.

Di Stefano M, Volpe A, Stallone G, Tartaglia L, Prato R, Martinelli D et al: Occult HBV infection in hemodialysis setting is marked by presence of isolated antibodies to $\mathrm{HBcAg}$ and HCV. J Nephrol 2009;22:381-386. 